\title{
Effects of body temperature on initial bite force in three species of rock- and crevice-dwelling lizards from Mexico
}

\author{
Guillermo A. Woolrich-Piña , Geoffrey R. Smith², Norberto Martínez-Méndez ${ }^{3}$, \\ Julio A. Lemos-Espinal ${ }^{4}$, Héctor Gadsden-Esparza ${ }^{5}$ \\ 1 Tecnológico Nacional de México, campus Zacapoaxtla, División de Biología, Subdirección de Investigación y Posgrado, Laboratorio de \\ Zoología y Ecofisiología. Carretera Acuaco-Zacapoaxtla Km. 8, Col. Totoltepec, Zacapoaxtla, C. P. 73680, Puebla, México \\ 2 Department of Biology, Denison University, Granville, Ohio 43023, USA \\ 3 Laboratorio de Bioconservación y Manejo, Departamento de Zoología, Escuela Nacional de Ciencias Biológicas, Instituto Politécnico \\ Nacional, Ciudad de México, C. P. 11340, Mexico \\ 4 Laboratorio de Ecología. UBIPRO, FES Iztacala, Universidad Nacional Autónoma de México. Av. De los Barrios \#1, Col. Los Reyes Iztacala, \\ Tlalnepantla, C. P. 54090, Estado de México, Mexico \\ 5 Instituto de Ecología, A. C.-Centro Regional del Bajío, Av. Lázaro Cárdenas 253, A. P. 386, Pátzcuaro, C. P. 61600, Michoacán, México \\ http://zoobank.org/932E9D39-0504-4398-8810-E0B7AC6B37F4
}

Corresponding author: Geoffrey R. Smith (smithg@denison.edu)

Academic editor: Johannes Foufopoulos • Received 5 February 2021 • Accepted 30 July 2021 • Published 19 August 2021

\begin{abstract}
Bite force can be an important aspect of a lizard's organismal performance, and is likely to be subject to influence by ambient conditions including an individual's thermal environment. We examined the effects of body temperature $\left(\mathrm{T}_{\mathrm{b}}\right)$ on initial bite force of rock- and crevice-dwelling individuals of three species of lizards: Abronia graminea (Anguidae), Barisia imbricata (Anguidae), and Xenosaurus fractus (Xenosauridae) from Mexico. In B. imbricata and X. fractus from one site (Xochititan, Puebla) initial bite force was greatest at intermediate $\mathrm{T}_{\mathrm{b}}$. In contrast, $X$. fractus from a second site (Tlatlauquitepec, Puebla) showed a weak tendency for initial bite force to increase with $\mathrm{T}_{\mathrm{b}}$. Initial bite force in A. graminea was not affected by $\mathrm{T}_{\mathrm{b}}$. Taking our results together, we infer that initial bite force in rock- or crevice-dwelling lizards is often, but not always, related to $T_{b}$.
\end{abstract}

\section{Key Words}

\section{Introduction}

For lizards, bite force, especially initial bite force, can be an important aspect of organismal performance. For example, bite force can play a role in determining the spectrum of prey an individual can consume (Meyers and Irschick 2015; da Silva et al. 2016; Dollion et al. 2017). In other cases, bite force can be important in determining the outcome of social interactions, whether that is mating/courtship, territoriality, aggressive behavior, or male-male combat (Lappin and Husak 2005; Donihue et al. 2016; Tseng et al. 2019). Thus, understanding what explains variation in bite force within and among species can be important for understanding variation in other aspects of organismal performance.

Body temperature can also potentially affect bite force in lizards. In general, maximal bite forces in ectotherms tend to increase with or peak at an optimal body temperature (Anderson et al. 2008) and thermal acclimation can affect skeletal muscle performance (James 2013). Indeed, body temperature has been shown to affect the performance of jaw muscles in agamid lizards (Herrel et 
al. 1999). However, bite force in some lizards is relatively unaffected by body temperature (Herrel et al. 2007; Cameron et al. 2018; Baxter-Gilbert and Whiting 2019), although there can be a significant drop in performance at the lowest body temperatures (Cameron et al. 2018).

Here, we examined the effects of temperature on initial bite force of rock-dwelling and crevice-dwelling individuals of three species of lizards: Terrestrial Arboreal Alligator Lizard, Abronia graminea (Anguidae); Imbricate Alligator Lizard, Barisia imbricata (Anguidae), and Xenosaurus fractus (Xenosauridae) from Mexico (Figure 1). Xenosaurus, especially, are very rarely seen outside their crevices (Lemos-Espinal et al. 2003, 2004; Maciel-Mata et al. 2020). Abronia graminea are typically arboreal but some individuals in some populations, including the one studied here, make extensive use of rock-related microhabitats, including crevices (G.A. Woolrich-Piña, unpubl. data). Temperature can influence the anti-predator response of lizards, with cooler lizards tending to adopt a fight response (e.g., biting, threatening) rather than a flight response (Hertz et al. 1982; Crowley and Pietruska 1983; Cury de Barros et al. 2010). Given the limited ability for lizards in crevices to thermoregulate and the relatively cool temperatures prevailing in the crevices used by the species in this study, we predict that the individuals would utilize an aggressive fight response rather than an escape response. The ability to bite may also be important in some of these species during intrasexual aggression (e.g., Barisia imbricata, Dashevsky et al. 2013; Xenosaurus spp., Ballinger et al. 1995; Smith et al. 1997; Herrel et al. 2001). The crevice or rock dwelling habits of these lizards may also be associated with an opportunistic foraging strategy (e.g.,, Woolrich-Piña et al. 2020), and therefore they may need to be able to capture and consume whatever potential prey they encounter regardless of the temperature. Finally, the microhabitat use of these lizards may limit their ability to thermoregulate or raise their body temperature (Woolrich-Piña et al. 2012, 2020). These observations lead us to predict that initial bite force would not be related to body temperature.

\section{Methods}

All lizards were collected from the Sierra Nororiental de Puebla (see Woolrich-Piña et al. 2017 for more details). We collected $A$. graminea $(\mathrm{N}=16)$ from rock-related microhabitats in cloud forest in the vicinity of Zacapoaxtla $\left(19^{\circ} 50^{\prime} 27^{\prime \prime} \mathrm{N}, 97^{\circ} 35^{\prime} 5^{\prime \prime} \mathrm{W}\right.$; datum = WGS84), $1920 \mathrm{~m}$ elevation, and B. imbricata $(\mathrm{N}=61)$ from thorn scrub and grassland transition habitat near the municipalities of Zaragoza and Ocotepec $\left(19^{\circ} 38^{\prime} 48^{\prime \prime N}\right.$, 97 $36^{\prime} 22^{\prime \prime} \mathrm{W}$; datum $=$ WGS84), elevation $2500 \mathrm{~m}$. We collected $X$. fractus from two populations: 1) a transition from cloud forest to pine-oak forest in the vicinity of Xochititan $(\mathrm{N}=19)$, municipality of Tetela de Ocampo (19 $53^{\prime} 15^{\prime \prime} \mathrm{N}$, 9745'54"W; datum = WGS84), 1700 m elevation.; and 2) pine-oak forest in Cerro Cabezón $(\mathrm{N}=17)$, near Tlat- lauquitepec (1951'48"N, 97³0'6"W; datum = WGS84), 1900 m elevation.

We measured snout-vent length (SVL) of each lizard with digital calipers (to nearest $0.01 \mathrm{~mm}$ ). We performed all experiments within $48 \mathrm{~h}$ of collection. We used $1.5 \mathrm{~m}^{3}$ temperature-controlled cabinets to create four temperature treatments $\left(\mathrm{T}_{\mathrm{c}}\right): 17,20,25$, and $30{ }^{\circ} \mathrm{C}$. We selected these temperature treatments because body, preferred, and environmental temperatures of these lizards are encompassed in this range of temperatures ( $X$. fractus: 9-30 ${ }^{\circ} \mathrm{C}$, Cardona-Botero et al. 2019; Woolrich-Piña et al. $2020 ;$ B imbricata, $9.1-36.6{ }^{\circ} \mathrm{C}$; Fierro-Estrada et al. 2019; no data available for $A$. graminea). Prior to the experiments we confirmed that each cabinet maintained the appropriate temperature over time using a data-logging Fluke 54 IIB digital thermometer (Fluke Corporation, Everett, Washington, USA). We randomly assigned individual lizards to a temperature treatment and placed them in individual plastic containers $(30 \mathrm{~cm} \times 15 \mathrm{~cm} \times$ $15 \mathrm{~cm}$ ) in the appropriate temperature cabinet for $12 \mathrm{hrs}$. Given the short period in captivity, we did not feed lizards but we did provide water. For Barisia imbricata we exposed 16 lizards to $17^{\circ} \mathrm{C}$ and $20^{\circ} \mathrm{C} ; 15$ to $25^{\circ} \mathrm{C}$, and 14 to $30^{\circ} \mathrm{C}$. For the Xenosaurus fractus from Xochititan, we exposed 5 lizards to $17{ }^{\circ} \mathrm{C}, 20^{\circ} \mathrm{C}$, and $25^{\circ} \mathrm{C}$; and 4 to $30{ }^{\circ} \mathrm{C}$. For the $X$. fractus from Tlatlauquitepec, we exposed 5 lizards to $17^{\circ} \mathrm{C}$ and 4 lizards to 20, 25, and $30{ }^{\circ} \mathrm{C}$. We exposed 4 Abronia graminea to each of the test temperatures. Each lizard was subjected to only one temperature treatment.

We constructed a bite force $(\mathrm{BF})$ recording device using an Arduino UNO board (Arduino, Ivrea, Italy) and a high accuracy commercial weight sensor (a $5 \mathrm{~kg}$ aluminum alloy IP65 single point load cell; type L6D accuracy class C5 [combined error $\leq \pm 0.014 \%$ ] International Organization of Legal Metrology R60 approval; Zemic Europe B.V., Etten-Laur, The Netherlands). We used a precision 24 bit analog-to-digital converter HX711 made by AVIA Semiconductor (AVIA Semi-conductor (Xiamen) Co., Ltd., Xiamen, China) to amplify the signal of the load cell to be processed in the Arduino board. The load cell was attached to a solid steel base that allowed us to fix the device to a table to avoid vibrations. Bite plates were made of steel and coated with leather and EVA foam to prevent injury and allow lizards to bite with full force. We calibrated the bite force meter using standard laboratory reference weights (OIML class E1; maximum permissible error from nominal value at $1 \mathrm{~kg}$ is $\pm 0.5 \mathrm{mg}$ ). We transformed the bite force data output into Newtons.

After $12 \mathrm{~h}$ of exposure to the different temperatures, we placed each lizard on a wooden platform at the level of the BF meter to prevent the lizard's mass from influencing the force exerted by the bite. We stimulated lizards to open their mouths by brushing their snouts with the bite bar perpendicular to the recording device and induced them to bite. The gape angle of all lizards was between $50^{\circ}$ and $53^{\circ}$ as measured with a transparent pro- 
tractor. The entire mouth of each lizard (i.e., from the tip of the snout to the junction of the supra and infralabials) was located within the bite bar, resulting in each bite being completed with the entire mouth. We only recorded $\mathrm{BF}$ for the first bite. We conducted all BF measurements inside the temperature-controlled cabinets to minimize changes in temperature, and recorded body temperature $\left(\mathrm{T}_{\mathrm{b}}\right.$ ) of each lizard (to nearest $0.1^{\circ} \mathrm{C}$ using a quick-reading cloacal thermometer; Miller and Weber, Inc., Ridgewood, New York, USA) immediately following the BF measurement to minimize stress on individuals that might influence the BF trials.

We obtained residuals of log-transformed BF by regressing them on log-transformed SVL for each species to examine the effects of temperature on BF independent of absolute body size effects (da Silva et al. 2014). To analyze the effect of body temperature $\left(\mathrm{T}_{\mathrm{b}}\right)$ on residual $\mathrm{BF}$, we used both a linear regression and a polynomial regression (i.e., including $\mathrm{T}_{\mathrm{b}}$ and $\mathrm{T}_{\mathrm{b}}{ }^{2}$ in the regression) using JMP Pro 15.1 (SAS Institute, Cary, North Carolina, USA). We used measured $T_{b}$ in our analyses rather than $T_{c}$ to best reflect lizards' actual temperature during the trial. In preliminary analyses, we found no significant differences in residual BF between males and females in any species, thus we pooled them in our analyses. In addition, preliminary analyses found limited effects of $\mathrm{HW}$ and no effects of HL on residual BF, and thus we did not include them in our analyses.

\section{Results}

A summary of mean SVL and absolute initial bite force is provided for each species in Table 1.

In Barisia imbricata, residual BF was not linearly related to $\mathrm{T}_{\mathrm{b}}\left(\mathrm{N}=61, \mathrm{r}^{2}=0.012, \mathrm{P}=0.40\right.$; however, there was a significant polynomial relationship between residual $\mathrm{BF}$ and $\mathrm{T}_{\mathrm{b}}$ such that residual $\mathrm{BF}$ was higher at intermediate $\mathrm{T}_{\mathrm{b}}$ (Fig. $1 \mathrm{~A} ; \mathrm{N}=61, \mathrm{r}^{2}=0.16, \mathrm{P}=0.0052$; residual $\left.\mathrm{BF}=-7.14+0.73 \mathrm{~T}_{\mathrm{b}}-0.018 \mathrm{~T}_{\mathrm{b}}{ }^{2}\right)$. The three remaining studies comprise comparatively little data, but can be used for added perspective. For example, there was an apparent trend, albeit statistically non-significant, for a positive linear relationship between residual $\mathrm{BF}$ and $\mathrm{T}_{\mathrm{b}}$ in Xenosaurus fractus from Tlatlauquitepec (Fig. 1B; $\mathrm{N}=17, \mathrm{r}^{2}=0.21$, $\mathrm{P}=0.066$; residual $\mathrm{BF}=-1.20+0.06 \mathrm{~T}_{\mathrm{b}}$ ), and the polyno-

Table 1. Mean ( \pm S.E.) snout-vent length (SVL) and initial bite force (as absolute bite force and residual bite force) for Barisia imbricata, Xenosaurus fractus from Tlatlauquitepec, Xenosaurus fractus from Xochititan, and Abronia graminea. $N$ is given in parentheses.

\begin{tabular}{lcc}
\hline & SVL $(\mathbf{m m})$ & Initial Bite Force $(\mathbf{N})$ \\
\hline B. imbricata (61) & $95.4 \pm 1.6$ & $5.6 \pm 0.5$ \\
X. fractus & & \\
$\quad$ Tlatlauquitepec (17) & $103.8 \pm 2.6$ & $6.9 \pm 0.8$ \\
Xochititan (19) & $96.6 \pm 2.4$ & $8.4 \pm 0.6$ \\
A. graminea $(16)$ & $99.8 \pm 2.4$ & $6.7 \pm 1.0$ \\
\hline
\end{tabular}

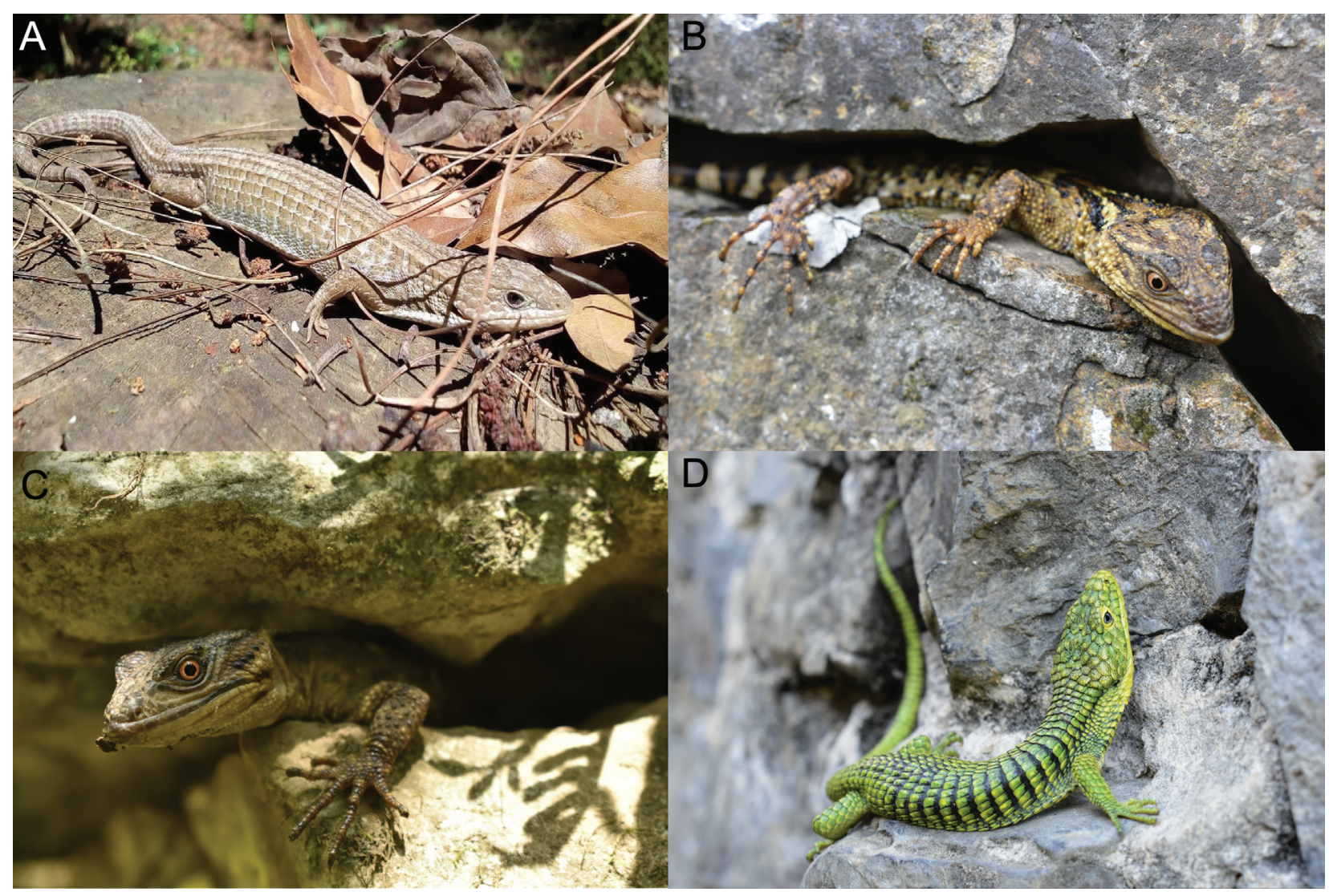

Figure 1. Photographs of A) Barisia imbricata, B) Xenosaurus fractus from Tlatlauquitepec, C) Xenosaurus fractus from Xochititan, and D) Abronia graminea. Photo credits: A: Guadalupe Yasmín González-González; B, C, D: Gerardo Gasca-Roldán. 

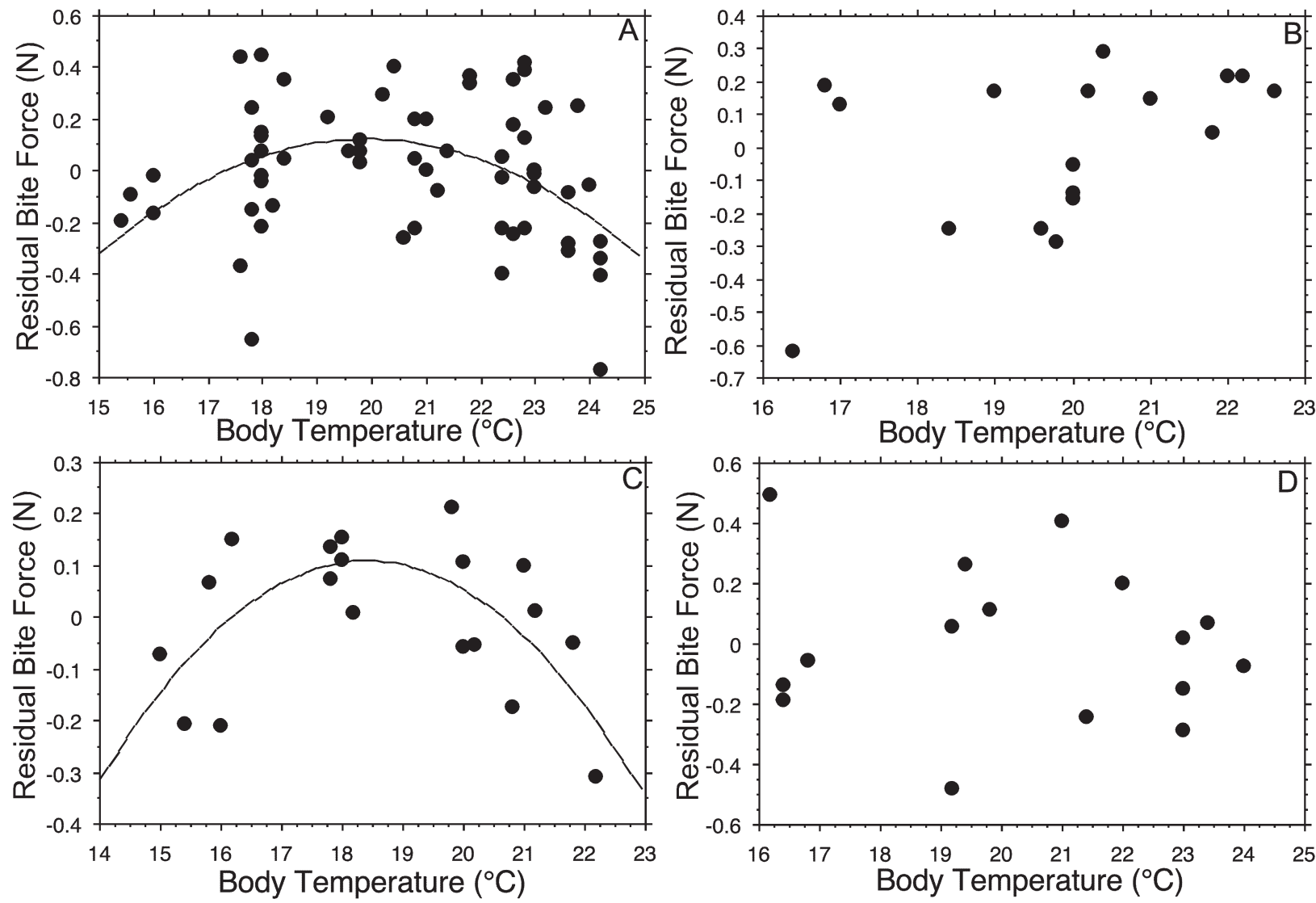

Figure 2. The relationship between residual bite force and body temperature for A) Barisia imbricata, B) Xenosaurus fractus from Tlatlauquitepec, C) Xenosaurus fractus from Xochititan, and D) Abronia graminea. Lines are provided for significant relationships $\left(\mathrm{A}: \mathrm{N}=61, \mathrm{r}^{2}=0.16, \mathrm{P}=0.0052 ;\right.$ residual $\mathrm{BF}=-7.14+0.73 \mathrm{~T}_{\mathrm{b}}-0.018 \mathrm{~T}_{\mathrm{b}}{ }^{2} ; \mathrm{C}: \mathrm{N}=19, \mathrm{r}^{2}=0.43, \mathrm{P}=0.011 ;$ residual $\mathrm{BF}=-7.28+$ $\left.0.80 \mathrm{~T}_{\mathrm{b}}-0.022 \mathrm{~T}_{\mathrm{b}}^{2}\right)$.

mial relationship between residual $\mathrm{BF}$ and $\mathrm{T}_{\mathrm{b}}$ was also not statistically significant $\left(\mathrm{N}=17, \mathrm{r}^{2}=0.22, \mathrm{P}=0.18\right)$. For $X$. fractus from Xochititan, the linear relationship between residual $\mathrm{BF}$ and $\mathrm{T}_{\mathrm{b}}$ was not significant $\left(\mathrm{N}=19, \mathrm{r}^{2}=0.009\right.$, $\mathrm{P}=0.70$ ); however, despite the low sample size, there was a significant polynomial relationship between residual BF and $T_{b}$ with intermediate $T_{b} s$ having higher residual $B F$ (Fig. 1C; $\mathrm{N}=19, \mathrm{r}^{2}=0.43, \mathrm{P}=0.011$; residual $\mathrm{BF}=-7.28$ $+0.80 \mathrm{~T}_{\mathrm{b}}-0.022 \mathrm{~T}_{\mathrm{b}}{ }^{2}$ ). Residual BF was not affected by $\mathrm{T}_{\mathrm{b}}$ in Abronia graminea (Fig. 1D; linear: $\mathrm{N}=16, \mathrm{r}^{2}=0.13$, $\mathrm{P}=0.67$; polynomial: $\mathrm{N}=16, \mathrm{r}^{2}=0.018, \mathrm{P}=0.89$ ), although the sample size was small.

\section{Discussion}

The three species of lizards we examined (A. graminea, $B$. imbricata, and $X$. fractus) showed different relationships between initial bite force and $\mathrm{T}_{\mathrm{b}}$. There were even differences in this relationship between the two populations of $X$. fractus. Thus, our hypothesis that there would be no relationship between initial bite force and $\mathrm{T}_{\mathrm{b}}$ was true for some, but not all, of these species and populations.

In $B$. imbricata initial bite force was highest at intermediate $\mathrm{T}_{\mathrm{b}}$. Mean $\mathrm{T}_{\mathrm{b}} \mathrm{s}$ of $B$. imbricata from populations in central Mexico range from $17.6^{\circ} \mathrm{C}$ to $26.6^{\circ} \mathrm{C}$ (Lemos-Espinal et al. 1998; Fierro-Estrada et al. 2019). The preferred body temperatures of $B$. imbricata ranged between $25.0^{\circ} \mathrm{C}$ and $31.3^{\circ} \mathrm{C}$ (quartile range) (Fierro-Estrada et al. 2019). The range of $\mathrm{T}_{\mathrm{b}} \mathrm{s}$ where we observed $B$. imbricata to have the greatest initial bite force $\left(17-23^{\circ} \mathrm{C}\right)$ coincides well with the range of observed mean $\mathrm{T}_{\mathrm{b}} \mathrm{s}$ but is lower than the observed preferred body temperatures, and perhaps initial bite force may be optimized at the $T_{b} s$ commonly encountered by these lizards.

Initial bite force in $X$. fractus from Xochititan was greatest at intermediate $\mathrm{T}_{\mathrm{b}}$. Mean $\mathrm{T}_{\mathrm{b}}$ of $X$. fractus from Xochititan was $19.67^{\circ} \mathrm{C}$ (range $10.6-23.8^{\circ} \mathrm{C}$ ) and preferred body temperature was $21.69{ }^{\circ} \mathrm{C}$ (range $=17.7-27.5^{\circ} \mathrm{C}$ ) (Woolrich-Piña et al. 2020). The peak in initial bite force in $X$. fractus from Xochititan is therefore similar to, but slightly lower than, the mean $\mathrm{T}_{\mathrm{b}}$ from previously published field observations, suggesting a match in the initial bite force and $T_{b}$ experienced in the field. Initial bite force from Tlatlauquitepec showed a weak tendency to increase linearly with body temperature. It thus appears that there might be differences in how initial bite force is affected by $\mathrm{T}_{\mathrm{b}}$ in these two populations of $X$. fractus. In addition, absolute BF appears to be greater in $X$. fractus from Xochititan than those from Tlatlauquitepec (see Table 1). 
This difference does not appear to be related to SVL since $X$. fractus from Xochititan are smaller than those from Tlatlauquitepec (see Table $1 ; \mathrm{F}_{1,34}=4.10, \mathrm{P}=0.05$ ). More study is needed to confirm and explore the explanations for these observed differences.

Initial bite force in $A$. graminea was not affected by $\mathrm{T}_{\mathrm{b}}$. Unfortunately, we are not aware of any field or laboratory studies on $\mathrm{T}_{\mathrm{b}}$ in A. graminea, or indeed other Abronia. We can therefore not relate our results with $\mathrm{T}_{\mathrm{b}} \mathrm{s}$ of $A$. graminea in nature. However, we infer from the lack of any detectable effect of $T_{b}$ in our experiment that initial bite force in these lizards is likely to be unaffected by environmental influences on $\mathrm{T}_{\mathrm{b}}$.

In conclusion, based on the one species with robust data, Barisia imbricata, initial bite force was greatest in the middle of the range of active body temperatures. A similar pattern was found in X. fractus from Xochititan. The other three datasets hint at different relationships between initial bite force and $\mathrm{T}_{\mathrm{b}}$. If the preliminary data on $X$. fractus are supported by larger data sets, then there may be differences in initial bite force, and its relationship with body temperature, between the two populations of $X$. fractus. Overall, our results thus provide mixed support for our hypothesis, and suggest that for at least some of these species, there is a role for temperature in determining initial bite force in these rock- and crevice-dwelling lizards.

\section{Acknowledgments}

We thank two anonymous reviewers for helpful comments on this manuscript. This study was funded by the CONACYT project 270547, TecNM project 5293.19-P and internal grants of the ITS Zacapoaxtla PI-LB granted to GAWP. In addition, la Subsecretaría de Educación Superior through the Dirección General de Educación Superior Universitaria e Intercultural and Dirección de Superación Académica granted the funds for a research academy on Ecology, Distribution and Conservation of Wildlife IDCA 27963, Clave ITESZACA-CA-4, 2020 2021. We thank A. Alvarado, J. Olvera, J. Arellano, Y. González, and S. Márquez for logistical support in the field and laboratory. Specimens were collected under a capture permit SEMARNAT SGPA/DGVS/01629/16 granted to F.R. Méndez de la Cruz. The work described here conformed with the laws of Mexico at the time of data collection and the guidelines for the use of amphibians and reptiles in research established by the American Society of Ichthyologists and Herpetologists, the Herpetologists' League, and the Society for the Study of Amphibians and Reptiles.

\section{References}

Anderson RA, McBrayer LD, Herrel A (2008) Bite force in vertebrates: opportunities and caveats for use of a nonpareil whole-animal per- formance measure. Biological Journal of the Linnean Society 93: 709-720. https://doi.org/10.1111/j.1095-8312.2007.00905.x

Ballinger RE, Lemos-Espinal J, Sanoja-Sarabia S, Coady NR (1995) Ecological observations of the lizard, Xenosaurus grandis, in $\mathrm{Cu}-$ autlapán, Veracruz, México. Biotropica 27: 128-132. https://doi. org/10.2307/2388910

Baxter-Gilbert JH, Whiting MJ (2019) Street fighters: Bite force, injury rates, and diversity of urban Australian water dragons (Intellagama lesueurii). Austral Ecology 44: 255-264. https://doi.org/10.1111/ aec. 12670

Cameron SF, Wheatley R, Wilson RS (2018) Sex-specific thermal sensitivities of performance and activity in the Asian house gecko, Hemidactylus frenatus. Journal of Comparative Physiology 188B: 635-647. https://doi.org/10.1007/s00360-018-1149-2

Cardona-Botero VC, Woolrich-Piña GA, Gadsden H (2019) Ecología térmica de dos especies de lagartijas del género Xenosaurus (Squamata: Xenosauridae) en México. Revista Mexicana de Biodiversidad 90: e902650. https://doi.org/10.22201/ib.20078706e.2019.90.2650

Crowley SR, Pietruszka RD (1983) Aggressiveness and vocalization in the leopard lizard (Gambelia wislizennii): The influence of temperature. Animal Behaviour 31: 1055-1060. https://doi.org/10.1016/ S0003-3472(83)80012-8

Cury de Barros F, de Carvalho JE, Abe AS, Kohlsdorf T (2010) Fight versus flight: the influence of temperature and body size determines antipredator behaviour in tegu lizards. Animal Behaviour 79: 83-88. https://doi.org/10.1016/j.anbehav.2009.10.006

Dashevsky, D., Meik JM, Mociño-Deloya E, Setser K, Schaack S (2013) Patterns of sexual dimorphism in Mexican alligator lizards, Barisia imbricata. Ecology and Evolution 3: 255-261. https://doi. org/10.1002/ece3.455

Da Silva JM, Carne L, Measey GJ, Herrel A, Tolley KA (2016) The relationship between cranial morphology, bite performance, diet and habitat in a radiation of swarf chameleon (Bradypodion). Biological Journal of the Linnean Society 119: 52-67. https://doi.org/10.1111/bij.12819

Da Silva JM, Herrel A, Measey GJ, Tolley KA (2014) Sexual dimorphism in bite performance drives morphological variation in chameleons. PLoS one 9(1): e86846. https://doi.org/10.1371/journal. pone. 0086846

Dollion AY, Measey GJ, Cornette R, Carne L, Tolley KA, da Silva JM, Boistel R, Fabre A-C, Herrel A (2017) Does diet drive the evolution of head shape and bite force in chameleons of the genus Bradypodion? Functional Ecology 31: 671-684.

Donihue CM, Brock KM, Foufopoulos J, Herrel A (2016) Feed or fight: testing the impact of food availability and intraspecific aggression on the functional ecology of an island lizard. Functional Ecology 30: 566-575. https://doi.org/10.1111/1365-2435.12550

Fierro-Estrada N, González González YG, Miles DB, Martínez Gómez M, García A, Salgado-Ugarte IH, Méndez de la Cruz FR (2019) Thermoregulation of the lizard Barisia imbricata at altitudinal extremes. Amphibia-Reptilia 40: 349-360. https://doi.org/10.1163/1568538120191155

Herrel A, Aerts P, Fret J, de Vree F (1999) Morphology of the feeding system in agamid lizards: Ecological correlates. Anatomical Record 254: 496-507. https://doi.org/10.1002/(SICI)10970185(19990401)254:4<496::AID-AR5>3.0.CO;2-Q

Herrel A, De Grauw E, Lemos-Espinal JA (2001) Head shape and bite performance in Xenosaurid lizards. Journal of Experimental Zoology 290: 101-107. https://doi.org/10.1002/jez.1039 
Herrel A, James RS, Van Damme R (2007) Fight versus flight: physiological basis for temperature-dependent behavioral shifts in lizards. Journal of Experimental Biology 210: 1762-1767. https://doi. org/10.1242/jeb.003426

Hertz PE, Huey RB, Nevo E (1982) Fight vs. flight: Body temperature influences defensive responses of lizards. Animal Behaviour 30: 676-679. https://doi.org/10.1016/S0003-3472(82)80137-1

James RS (2013) A review of the thermal sensitivity of the mechanics of vertebrate skeletal muscle. Journal of Comparative Physiology 183B: 723-733. https://doi.org/10.1007/s00360-013-0748-1

Lappin AK, Husak JF (2005) Weapon performance, not size, determines mating success and potential reproductive output in the collared lizard (Crotaphytus collaris). American Naturalist 166: 426-436. https://doi.org/10.1086/432564

Lemos-Espinal JA, Smith GR, Ballinger RE (1998) Temperature relationships of the lizard, Barisia imbricata, from México. Amphibia-Reptilia 19: 95-99. https://doi.org/10.1163/156853898X00368

Lemos-Espinal JA, Smith GR, Ballinger RE (2003) Variation in growth and demography of knob-scaled lizard (Xenosaurus newmanorum: Xenosauridae) from a seasonal tropical environment in Mexico. Biotropica 35: 240-249. https://doi.org/10.1111/j.1744-7429.2003. tb00283.x

Lemos-Espinal JA, Smith GR, Ballinger RE (2004) Aspects of the ecology of a distinct population of Xenosaurus platyceps from
Queretaro, Mexico. Amphibia-Reptilia 25: 204-210. https://doi. org/10.1163/1568538041231166

Maciel-Mata CA, Alanis-Hernández LA, Flores-Hernández MA (2020) Xenosaurus tzacualtipantecus. Atypical behavior. Herpetological Review 51: e857.

Meyers JJ, Irschick DJ (2015) Does whole-organism performance constrain resource use? A community test with desert lizards. Biological Journal of the Linnean Society 115: 859-868. https://doi. org/10.1111/bij.12537

Smith GR, Lemos-Espinal JA, Ballinger RE (1997) Sexual dimorphism in two species of knob-scaled lizards (genus Xenosaurus) from Mexico. Herpetologica 53: 200-205.

Tseng H-Y, Liao C-P, Hsu J-Y, Wang L-Y, Huang W-S (2019) Parental behaviour drives large bite force in an insular skink population. Journal of Zoology 307: 223-231. https://doi.org/10.1111/jzo.12638 Woolrich-Piña GA, García-Padilla E, De Santis DL, Johnson JD, Mata-Silva V, Wilson LD (2017) The herpetofauna of Puebla, Mexico: the herpetofauna of Puebla, Mexco: composition, distribution, and conservation status. Mesoamerican Herpetology 4: 791-837.

Woolrich-Piña GA, Smith GR, Lemos-Espinal JA, Márquez-Guerra S, Alvarado-Hernández A, García-Montiel JC (2020) Ecology of Xenosaurus fractus (Squamata: Xenosauridae) from Sierra Nororiental, Puebla, Mexico. Current Herpetology 39: 1-12. https://doi. org/10.5358/hsj.39.1 